ISSN : $2302-1590$

E-ISSN: $2460-190 \mathrm{X}$

ECONOMICA

Journal of Economic and Economic Education Vol.5 No.1 (1-5)

\title{
PENGARUH MEDIA PEMBELAJARAN POWER PONT TERHADAP HASIL BELAJAR MATERI HUKUM PERUSAHAAN PADA MAHASISWA 2014 SESI F PENDIDIKAN EKONOMI STKIP PGRI SUMBAR
}

\author{
Jimi Ronald \\ Dosen Program Studi Pendidikan Ekonomi STKIP- PGRI Sumbar \\ Jl. Gunung Pangilun No.1, Padang Sumatera Barat \\ Email: jimironald@ymail.com \\ submited: 2015.12.04 reviewed: 2016.01.11 accepted: 2016.10 .12 \\ http://dx.doi.org/10.22202/economica.2016.v5.i1.328
}

\begin{abstract}
This research was aimed at finding the effect of using the 'Power Point 'media to the result of the learning the students' learning result in the subject of Economy. The research was a quasiexperiment whose population was grade XI IPS students of 2014 Economic Education STKIP PGRI SUMBAR. The sampling technique used was the purposive sampling. The Sample is Student 2014 F Economic Education STKIP PGRI SUMBAR. The data of the research consisted of two kinds : primary and secondary data. The data were analyzed by using a descriptive method. In the descriptive analysis techniques are the learning outcomes of students who achieve mastery of $75 \%$ and which did not achieve mastery of $25 \%$.

Abstrak

Penelitian ini bertujuan untuk mengungkap mahasiswa yang diajarkan dengan media power point memiliki hasil belajar lebih tinggi. Jenis penelitian adalah quasi eksperimen. Populasi penelitian adalah mahasiswa 2014 pendidikan ekonomi STKIP PGRI SUMBAR. Teknik pengambilan sampel adalah Purposive Sampling. Sampel adalah mahasiswa 2014 F pendidikan ekonomi STKIP PGRI SUMBAR. Jenis data terdiri dari data primer dan data sekunder, sedangkan teknik analisis data adalah deskriptif. Pada teknik analisis deskriftif terdapat hasil belajar mahasiswa yang mencapai ketuntasan sebesar $75 \%$ dan yang tidak mencapai ketuntasan sebesar $25 \%$.
\end{abstract}

Keywords: Power Point media, students learning result in the subject of Economy 


\section{PENDAHULUAN}

Pendidikan merupakan suatu sarana dan wadah untuk mengembangkan pengetahuan manusia baik itu secara formal maupun informal. Salah satu wadah formal megembangkan pengetahuan manusia adalah melalui perkuliahan di kampus STKIP PGRI SUMBAR yang terdiri dari berbagai macam ilmu pengetahuan seperti; ilmu pengetahuan geografi, sejarah, sosiologi, bahasa Indonesia, bahasa inggris, bologi, fisika, kimia, matematika, informatika, budi pekerti dan ekonomi. Salah satu pengetahuan yang banyak diminati oleh mahasiswa STKIP PGRI SUMBAR adalah ilmu ekonomi. Ekonomi merupakan suatu pengetahuan yang mempelajari tentang kebutuhan manusia yang tidak terbatas sedangkan alat pemuasan kebutuhannya terbatas. untuk mengetahui apakah mahasiswa STKIP PGRI SUMBAR memiliki pengetahuan tentang ekonomi bisa dilihat dari hasil belajarnya, salah satunya kita bisa melihat hasil belajar mahasiswa pendidikan ekonomi STKIP PGRI SUMBAR. Menurut Djamarah (2002:25) Hasil belajar diartikan sebagai hasil akhir pengambilan keputusan tentang tinggi rendahnya nilai siswa selama mengikuti proses belajar mengajar, pembelajaran dikatakan berhasil jika tingkat pengetahuan siswa bertambah dari hasil sebelumnya. Untuk mengukur apakah hasil belajar mahasiswa ekonomi tinggi kita bisa melihat tabel di bawah ini:

Tabel 1. Rata-rata hasil belajar mahasiswa pendidikan ekonomi STKIP PGRI SUMBAR Pada Mata Kuliah Hukum Perdata Dan Dagang Materi Hukum Perdata

\begin{tabular}{lcccc}
\hline Angkatan & $\begin{array}{c}\text { Jumlah } \\
\text { Mahasiswa }\end{array}$ & $\begin{array}{l}\text { Rata - rata Hasil } \\
\text { Belajar } \\
\text { Materi } \\
\text { Perdata }\end{array}$ & Tuntas & Tidak Tuntas \\
& \multicolumn{2}{c}{75} & & \\
\hline $2014 \mathrm{E}$ & 45 & 60 & 30 & 15 \\
$2014 \mathrm{~F}$ & 45 & 84 & 37 & 34 \\
$2014 \mathrm{G}$ & 45 & 24 & 37 \\
\hline
\end{tabular}

Sumber : Dosen Mata Kuliah Hukum Perdata Dan Dagang Pendidikan Ekonomi STKIP PGRI SUMBAR

Dari tabel di atas terlihat hasil belajar mahasiswa masih ada yang rendah, pada angkatan $2014 \mathrm{E}$ dengan jumlah mahasiswa 45 orang yang memiliki nilai rata-rata hasi belajar sebesar 75 dimana yang tuntas 30 orang sedangkan yang tidak tuntas 15 orang. Pada angkatan $2014 \mathrm{~F}$ dengan jumlah mahasiswa 45 orang yang memiliki nilai rata-rata hasi belajar sebesar 60 dimana yang tuntas 11 orang sedangkan yang tidak tuntas 34 orang. Sedangkan pada angkatan 2014 G dengan jumlah mahasiswa 45 orang yang memiliki nilai rata-rata hasi belajar sebesar
84 dimana yang tuntas 37 orang sedangkan yang tidak tuntas 8 orang. Banyak faktor yang mempengaruhi hasil belajar, baik yang berasal dari dalam diri maupun luar diri kita. Menurut Sabri (2007:45) faktor yang mempengaruhi hasil belajar adalah berasal dari dalam diri siswa (motivasi belajar, minat, perhatian, kebiasaan belajar, dan ketekunan) dan luar diri siswa (lingkungan belajar dan kualitas pengajaran).

Masih rendahnya hasil belajar mahasiswa pendidikan ekonomi angkatan 2014 ini disebabkan oleh masih banyak dosen menggunakan metode pembelajaran yang tidak sesuai dengan materi pemebelajaran 
sehingga mahasiswa menjadi jenuh, kurang semangat, tidak memperhatikan, tidak aktif dalam bertanya, dan banyak yang keluar masuk kelas sehingga menyebabkan hasil belajar mahasiswa rendah.

Salah satu cara untuk mengatasi rendahnya hasi belajar dengan menggunakan media pembelajaran yang bervariatif sehingga mampu meningkatkan motivasi dan semangat mahasiswa untuk belajar. Ini sejalan dengan media pembelajaran Power Pont membantu dosen dalam penyampaian pembelajaran.. Dengan media ini diharapkan mahasiswa mampu meningkatkan hasil belajarnya.

Dari penjelasan di atas, pentingnya penelitian ini dilakukan adalah untuk melihat sejauhmana metode pembelajaran sosiodrama terhadap hasil belajar siswa pada materi hukum dagang. Untuk itu penulis tertarik melakukan penelitian yang berjudul judul "Pengaruh Media Pembelajaran Power Pont Terhadap Hasil Belajar Materi Hukum Perusahaan Pada Mahasiswa 2014 Sesi F Pendidikan Ekonomi STKIP PGRI SUMBAR"

\section{HASIL BELAJAR}

Hasil belajar adalah kemampuankemampuan yang dimiliki peserta didik setelah ia menerima pengalaman belajarnya. Hasil belajar tersebut digunakan untuk dijadikan ukuran atau kriteria dalam mencapai suatu tujuan pendidikan. Hal ini dapat tercapai apabila peserta didik sudah memahami belajar dengan diiringi oleh perubahan tingkah laku yang lebih baik lagi. Menurut Sudjana (2010:22), hasil belajar adalah kemampuan yang dimiliki siswa setelah menerima pengalaman belajar.

Sedangkan menurut Dimyati (2006:4) "hasil belajar dapat dibedakan menjadi dua yaitu dampak pengajaran dan penggiring". Dampak pengajaran adalah hasil yang dapat diukur, seperti nilai dalam rapor, angka dalam ijazah atau kemampuan meloncat setelah latihan. Dampak penggiring adalah terapan pengetahuan dan kemampuan dibidang lain, suatu transfer belajar. Dengan adanya kedua dampak ini diharapkan bisa meningkatkan hasil belajar siswa.

\section{FAKTOR - FAKTOR YANG MEMPENGARUHI HASIL BELAJAR}

Menurut Sardiman (2009: 38) mengatakan bahwa hasil belajar dipengaruhi oleh pengalaman subjek belajar dengan dunia fisik dan lingkungannya. Hasil belajar seseorang tergantung pada apa yang telah diketahui, si subjek belajar, tujuan, motivasi yang mempengaruhi proses interaksi dengan bahan yang sedang dipelajari. Sejalan dengan itu, Sabri (2007:45) faktor yang mempengaruhi hasil belajar adalah berasal dari dalam diri siswa (motivasi belajar, minat, perhatian, kebiasaan belajar, dan ketekunan) dan luar diri siswa (lingkungan belajar dan kualitas pengajaran). Dengan memperhatikan faktor-faktor tersebut diharapkan dapat meningkatkan hasil belajar seseorang dan dapat mencegah siswa dari penyebab-penyebab terhambatnya pembelajaran.

\section{MEDIA POWER POINT}

(Sebaya, 2011) Diantara media pembelajaran yang disarankan adalah menggunakan media power point. Kita ketahui bahwa dalam penggunaan media power point dengan mengoperasikan sarana pendukung berupa seperangkat komputer atau laptop dan LCD sebagai media pembelajaran. Bahan power point untuk mempresentasikan materi pelajaran bisa dibuat melalui program komputer sesuai dengan keinginan kita. Yang lebih menarik adalah materi itu bisa ditayangkan dengan menggunakan LCD (Liquid Cristal Display) Projector, sama seperti layar monitor di mana peserta didik bisa melihat dengan enak 
dan nyaman.Tampilan dapat berupa penggabungan teks, gambar atau foto bahkan suara sebagai efek sehingga menambah daya tarik tersendiri. Melalui program komputer, hasil dari bahan power point tersebut bisa diubah menjadi gamba hidup dan bersifat dinamis. Media Power Point sangatlah menjadi andalan bagi seseorang untuk menyampaikan sesuatu kepada orang lain. Berkaitan dengan hal tersebut, beberapa hal tentang manfaat dari media power point antara lain:

1. Untuk menjelaskan flow chart atau diagram alir untuk program tertentu

2. Untuk menampilkan gambar atau proses yang tidak mungkin ditunjukkan secara langsung. Sedemikian

(Sebaya, 2011) Adapun kelebihannya adalah sebagai berikut:

1. Dapat menggabungkan teks dan gambar

2. Dapat memasukkan hitungan dan tabel sebagai pendukung dari materi kita

3. Dapat disisipkan gambar atau foto bahkan video dan animasi dari berbagai program ataupun karya sendiri

4. Mudah disunting atau diedit antara lain menghapus, memindahkan dan menyalin slide, bahkan menyisipkan slide baru

5. Tampilan slide dapat disesuaikan dengan keinginan kita baik tulisan atau munculnya slide dengan berbagai Untuk menjelaskan struktur organisasi

6. Untuk memperkenalkan suatu produk

7. Untuk menjelaskan materi atau program versi

8. Tidak ada batasan lembar atau slide pada materi yang akan kita tampilkan

9. Kita dapat memberikan penekanan pada materi yang dianggap lebih penting dengan memberikan warna atau ukuran huruf yang berbeda pada bagian yang kita inginkan

10. Kita dapat memilih latar belakang slide sesuai dengan materi sehingga peserta didik akan lebih jelas dalam memperhatikan materi

11. Kita dapat memanggil materi sebelum atau sesudah yang kita terangkan dengan cepat

12. Dapat ditambahkan system audio sehingga tampilan memberikan informasi dan pengetahuan yang tidak membosankan

13. Materi yang kita gunakan mempunyai daya simpan yang lama dan dapat kita perbaharui kapanpun

14. Materi dapat kita gandakan dengan cepat Namun demikian,

\section{METODE PENELITIAN}

Sesuai dengan permasalahan yang diteliti maka jenis penelitian ini termasuk penelitian Quasi eksperimen. Menurut Sugiyono (2010:114) Quasi eksperimen adalah eksperimen yang memiliki perlakuan (treatments), pengukuranpengukuran dampak (outcome measures), dan unit-unit eksperiment (experimental units) namun tidak menggunakan penempatan secara acak.

Penelitian dilaksanakan di kelas angkatan 2014 F mahasiswa pendidikan ekonomi STKIP PGRI SUMBAR. Jumlah subjek penelitian 45 mahasiswa. Waktu penelitian dilaksanakan mulai bulan November 2015 sampai bulan desember 2015 pada semester ganjil tahun ajaran 2015/2016. Adapun alat pengumpulan data dalam penelitian ini, yaitu instrumen tes. Instrumen tes berupa lembar soal evaluasi hasil belajar siswa,

POPULASI DAN SAMPEL 
Populasi dalam penelitian ini adalah mahasiswa pendidikan ekonomi STKIP PGRI SUMBAR sesi 2014 E, F, dan G yang terdaftar pada tahun pelajaran 2015/2016 yang berjumlah 135 mahasiswa. Sampel pada penelitian ini adalah mahasiswa pendidikan ekonomi STKIP PGRI SUMBAR sesi 2014 F. Sampel penelitian ini berjumlah 45 orang mahasiswa.

\section{TEKNIK ANALISIS DATA}

Teknik analisis data pada penelitian ini hanya menggunakan teknik analisis deskriptif. Analisis ini bertujuan menggambarkan data apa adanya yang dikumpulkan dari responden. Adapun variabel yang dideskriptifkan adalah semua variabel yang diteliti dengan cara menghitung persentase, standar deviasi, median, modus, koevisien varians untuk hasil belajar ekonomi,

Pada awal pelaksanaan penelitian, penulis menetapkan materi pelajaran yang akan disampaikan pada kelas sampel, materi pelajaran yang dipilih penulis adalah pokok bahasan hukum perusahaan yang diterapkan media pembelajaran Power Point. Pelaksanaan posstest berguna untuk melihat kemampuan mahasiswa pada kelas sampel setelah diberi perlakuan proses pembelajaran.

\section{PEMBAHASAN}

dari penyebaran distribusi hasil belajar nilai terendah yang diperoleh mahasiswa adalah 70 dan nilai tertinggi adalah 95, modus sebesar 84, median sebesar 82, serta ratarata hasil belajar sebesar 82. Dari hasil penyebaran distibusi hasil belajar ini diperoleh $75 \%$ mahasiswa telah mencapai ketuntasan sedangkan $25 \%$ mahasiswa belum mencapai nilai ketuntasan.

\section{PENUTUP}

\section{Simpulan}

Berdasarkan hasil penelitian dan pembahasan penelitian ini, dapat diambil kesimpulan bahwa Media pembelajaran Power Pont berpengaruh terhadap hasil belajar materi hukum Perusahaan mahasiswa $2014 \mathrm{~F}$ pendidikan ekonomi STKIP PGRI SUMBAR.

\section{Saran}

Berdasarkan temuan dan implikasi penelitian di atas maka disini peneliti menyampaikan beberapa saran sebagai berikut: Dengan melihat hasil temuan di atas penulis menyarankan agar dosen menggunakan Media pembelajaran Power Pont pada mahasiswa pendidikan ekonomi STKIP PGRI SUMBAR.

\section{DAFTAR PUSTAKA}

10.22202/economica.2016.v5.i1.328

Dimyati dan Mudjiono.2003.Belajar dan Pembelajaran.Jakarta:

Depdikbud

Sebaya, T. (2011). Issn : 2337-3253, 5, 111.

Sabri, Ahmad. 2007. Strategi Belajar Mengajar Dan Micro Teaching. Ciputat: Quantum Teaching

Sardiman. 2009. Interaksi dan Motivasi Belajar Mengajar. Jakarta: Rajawali Pers.

Sudjana, Nana. 2010. Dasar-Dasar Proses Belajar Mengajar. Bandung: Sinar baru algensindo offset

Sugiyono. 2010. Metode Penelitian Pendidikan Pendekatan Kuantitatif, Kualitatif, dan R\& D. Bandung: Alfa Beta

Sebaya, T. (2011). Issn : 2337-3253, 5, 111. 